\title{
Peningkatan Sadar Investasi Masyarakat melalui Model Penta Helix
}

\author{
Muhammad Al Faridho Awwal', Dewi Wahyu Setyo Rini² \\ Fakultas Ekonomi dan Bisnis Islam, \\ Univeristas Islam Negeri Sunan Kalijaga Yogyakarta, Indonesia
}

$\triangle$ Corresponding Author:

Nama Penulis: Muhammad Al Faridho Awwal

E-mail: mafaalial@gmail.com

\begin{abstract}
In 2017, Indonesia takes the title of worth-invested country, supported by the fact that Indonesia has accredited by United Nation Conference on Trade and Developments (UNCTAD) as one of the countries with prospective investation target. Furthermore, investation also become an important part of Indonesian economy as President Joko Widodo said that investation become the key of improvement for Indonesian economy. Stock market's growths in Indonesia is actually quite good, although its literacy rate is not so much. This research focused on strategy to grow the literacy rate of stock market in order to increase society's awareness through the synergies and roles of stackholders. We take one of the government's program which is Yuk Nabung Saham as the research's object. Data that are being used here is in the form of primary data of interviews' results and secondary data then described and interpreted. In the development of the said program, we used penta helix Model that involves five stackholders. Then, we used Laku Pandai program in collaboration with three stackholders. With this program we hoped that it could increase society's awareness about the importance of investation especially on stock market and we also hoped that it could increase the number of society's investment in Indonesia that could give good impact to the economy of the country.
\end{abstract}

Keywords: Investment Awareness, Stock Market, Yuk Nabung Saham, Penta Helix

\begin{abstract}
Abstrak: Di tahun 2017 Indonesia memperoleh predikat negara layak investasi, hal ini didukung dengan naiknya peringkat Indonesia sebagai negara tujuan investasi yang prospektif menurut United Nation Conference on Trade and Developments (UNCTAD). Selain itu, investasi juga menjadi hal penting bagi perekonomian Indonesia. Hal ini selaras dengan pernyataan Presiden Joko Widodo yang menyebutkan bahwa investasi merupakan kunci peningkatan ekonomi Indonesia. Di Indonesia sendiri investasi sudah mendapat lahan pasar sendiri melalui pasar modal. Perkembangan pasar modal di Indonesia terhitung baik. Namun, hal ini belum diimbangi dengan angka literasinya. Penelitian ini difokuskan pada strategi peningkatan literasi pasar modal yang bertujuan untuk peningkatan masyarakat sadar investasi melalui sinergi dan peran


Muhammad Al Faridho Awwal, Dewi Wahyu Setyo Rini

stakeholder dengan metode kualitatif. Peneliti mengambil sebuah program pemerintah yaitu Yuk Nabung Saham sebagai objek penelitian. Data yang digunakan berupa data primer hasil wawancara dan data sekunder yang kemudian dideskripsikan serta ditafsirkan secara sistematis yang kemudian menghasilkan sebuah kesimpulan. Dalam pengembangan program tersebut, peneliti menggunakan model penta helix dengan melibatkan lima stakeholder. Selanjutnya, peneliti memasukkan program laku pandai dalam collaborating tiga stakeholder. Melalui program ini diharapkan dapat meningkatkan kesadaran masyarakat akan pentingnya investasi serta dapat meningkatkan angka investasi di Indonesia sehingga mampu meningkatkan perekonomian Indonesia.

Keywords: Sadar Investasi, Pasar saham, Yuk Nabung Saham, Penta Helix

\section{Cara mencitasi:}

Awwal, M.A., Rini, D.W.S. (2019). Peningkatan Sadar Investasi Masyarakat melalui Model Penta Helix. Iqtishoduna. Vol. 15 (2): pp. 153-180

\section{Pendahuluan}

Investasi merupakan penanaman modal (baik modal tetap maupun modal tidak tetap) yang digunakan dalam proses produksi untuk memperoleh keuntungan suatu perusahaan. Investasi penting bagi kelanggengan masa depan perusahaan, tetapi juga merupakan topik yang secara konseptual sulit dan komplek (Sumastuti, 2006). Perkembangan investasi di Indonesia terbilang cukup signifikan, terlebih terdapat tempat khusus yang menjalankan transaksi investasi atau dikenal dengan perdagangan efek yaitu pada pasar modal. Pasar modal dan kebijakannya tercantum dalam Undang-undang No 8 Tahun 1995 beserta peraturan pelaksanaannya yang tercantum dalam Peraturan Bapepam LK, Peraturan Pemerintah, Peraturan Bursa dan lain-lain. Menurut UU No 8 Tahun 1995 pasar modal didefinisikan sebagai kegiatan yang bersangkutan dengan penawaran umum dan perdagangan efek, perusahaan publik yang berkaitan dengan efek yang diterbitkannya serta lembaga dan profesi yang berkaitan dengan efek.

Di Indonesia pasar modal berkembang dengan dua jenis yakni pasar modal dan pasar modal syariah. Pasar modal syariah melayani jenis investasi syariah dan semua transaksi efek sesuai dengan prinsip syariah. Dalam publikasi OJK menyebutkan pasar modal syariah bukanlah suatu sistem yang terpisah dari sistem pasar modal secara keseluruhan (Direktorat Pasar Modal Syariah Otoritas Jasa Keuangan, t.t). Secara umum kegiatan pasar modal syariah tidak memiliki perbedaan dengan pasar modal, namun pasar modal syariah memiliki karakteristik khusus yaitu produk dan mekanisme transaksi yang tidak bertentangan dengan prinsip-prinsip syariah. Munculnya investasi syariah dimulai tahun 1997 dan mencapai tonggak sejarah baru dengan disahkannya UU Nomor 19 tahun 2008 tentang Surat Berharga Syariah 154| IQTISHODUNA Vol. 15 No. 2 Tahun 2019 http://ejournal.uin-malang.ac.id/index.php/ekonomi 
Negara (SBSN). Munculnya pasar modal syariah sebagai upaya peningkatan inklusi pasar modal yang masih sangat minim dibandingkan industri keuangan lainnya. Berikut indeks inklusi keuangan berdasarkan sektor keuangan.

Grafik 1. Indeks Inklusi Keuangan Nasional Tahun 2013 \& 2016

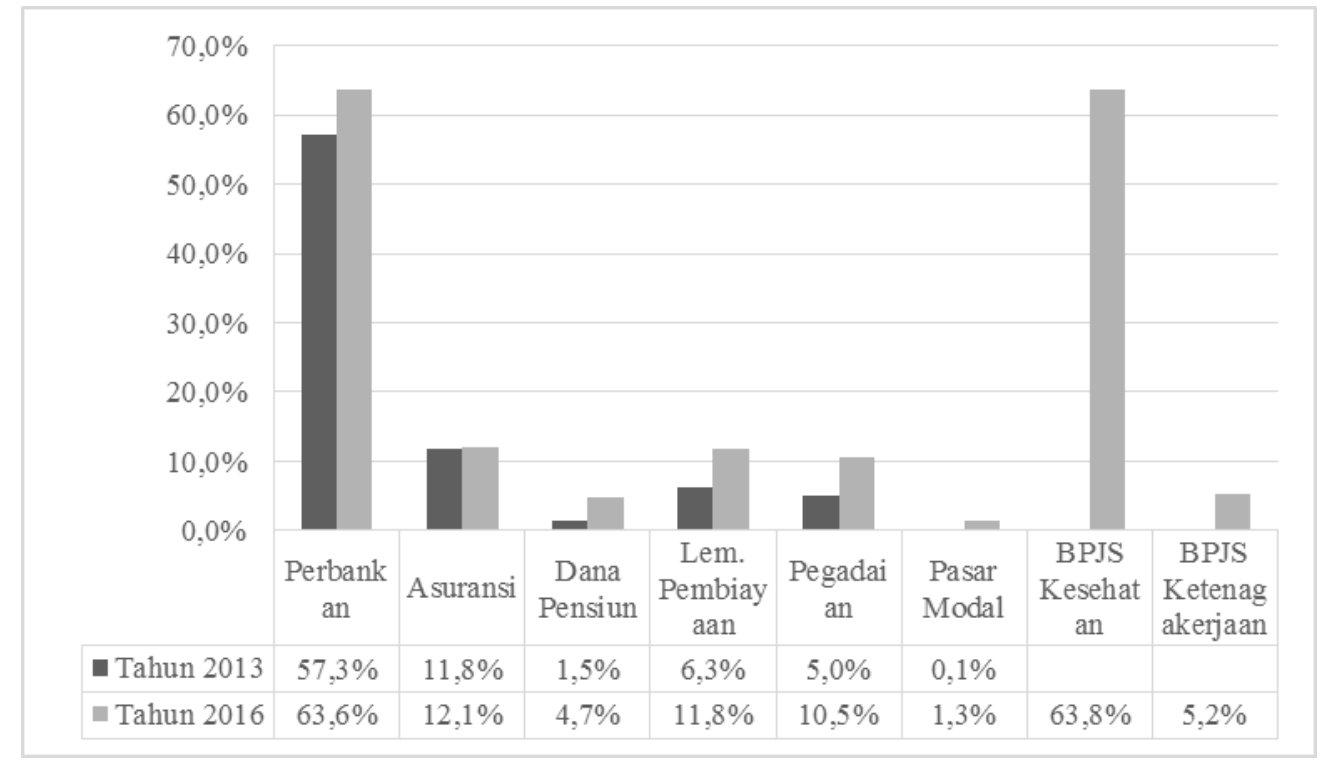

Sumber : Publikasi OJK dengan Judul Strategi Nasional Literasi Keuangan Indonesia (Revisit 2017), data diolah lagi oleh peneliti

Di tahun 2016 indeks pasar modal secara nasional hanya 1,3\% dibandingkan inklusi keuangan di sektor lain dengan investor domestik hanya $0.2 \%$. Indeks tersebut sejalan dengan tingkat literasi masyarakat Indonesia terhadap sektor jasa keuangan. Kepala Departemen Literasi dan Inklusi Keuangan Otoritas Jasa Keuangan (OJK) Agus Sugiarto mengatakan pencapaian target inklusi keuangan harus dibarengi dengan upaya peningkatan literasi keuangan. Data Hasil Survei Literasi Keuangan Nasional digambarkan dalam grafik 2 . 
Grafik 2. Indeks Literasi Keuangan Nasional Tahun 2013 \& 2016

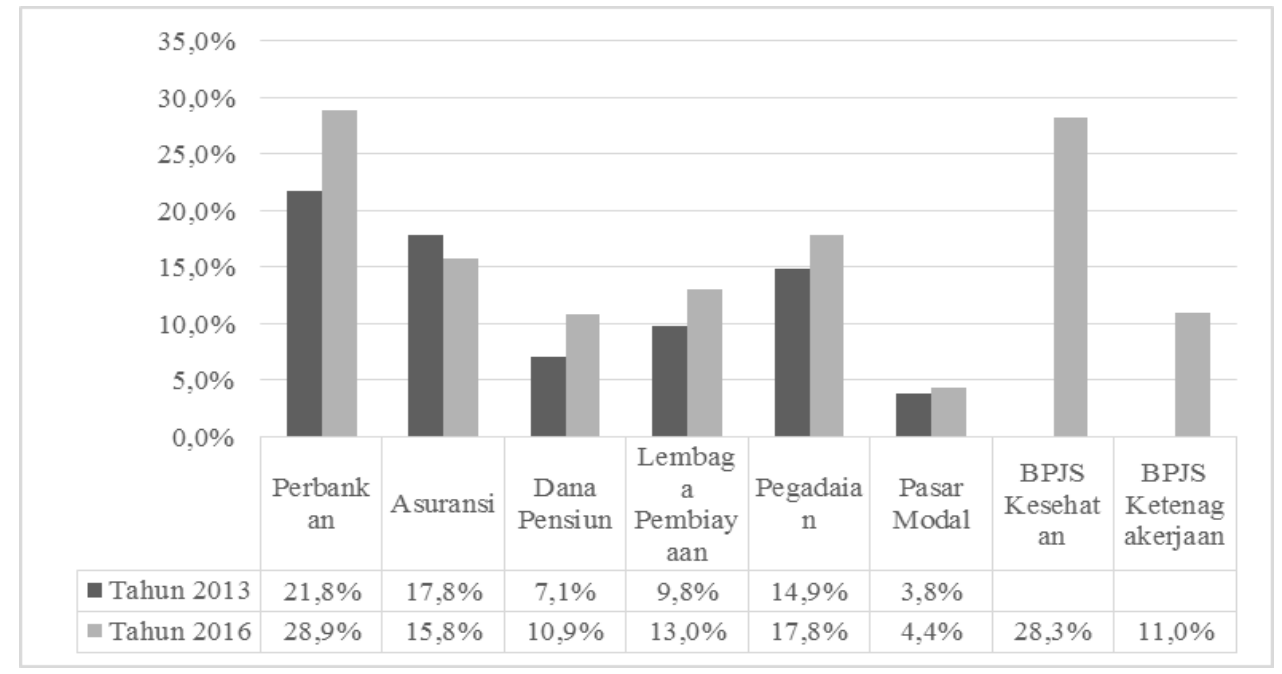

Sumber: Otoritas Jasa Keuangan, 2016

Dalam perkembangan literasi keuangan sekalipun, pasar modal masih berada pada indeks terendah dari semua industri jasa keuangan. Tentu hal ini menjadi tantangan tersendiri bagi para pemangku kepentingan untuk terus meningkatkan inklusi serta literasi pasar modal.

Peningkatan investasi melalui pasar modal harus mendapat perhatian khusus. Mengingat di tahun 2017 Indonesia memperoleh predikat negara layak investasi (Himawan \& Tanjung, 2017). Selain itu, United Nations Conference on Trade and Developments (UNCTAD) pada Juni 2017 menempatkan Indonesia di peringkat keempat dan menurut survei US News bulan Maret 2018 peringkatnya naik menjadi kedua sebagai negara tujuan investasi yang prospektif dalam kurun waktu 2017-2019 (Himawan \& Tanjung, 2017). Selain dalam kancah internasional, secara nasional investasi berpengaruh positif terhadap pertumbuhan ekonomi. Sebagian ahli ekonomi memandang bahwa pembentukan investasi merupakan salah satu faktor pertumbuhan ekonomi di Indonesia. Ketika pengusaha atau individu mengeluarkan uang atau modal atau barang yang tidak dikonsumsi tetapi digunakan untuk produksi, hal tersebut akan menghasilkan barang atau keuntungan kembali di masa akan datang. Dalam kata lain, pengeluaran konsumsi untuk investasi akan mendatangkan keuntungan bagi investor dan debitur, mengingat dari pengelolaan dana konsumsi investasi akan menghasilkan keuntungan. Dari uraian tersebut, pengelolaan dana investasi juga dapat mengurangi pengangguran karena adanya pengelolaan suatu dan investasi yang tentu membutuhkan sumber daya manusia. Hal ini juga diperkuat oleh Keynes dan Jhingan (2003) yang menyebutkan bahwa pertumbuhan ekonomi berkorelasi positif dengan investasi. Keynes juga menyarankan agar pemerintah meningkatkan pengeluaran karena 
memandang pemerintah sebagai agen independen yang mampu menstimulasi perekonomian melalui kerja publik. Pada masa resesi, kenaikan pengeluaran pemerintah (G) akan mendorong konsumsi (C) dan investasi (I), dan karenanya menaikkan pendapatan nasional. Hal ini sejalur dengan rumus perhitungan GDP (Gross Domestic Product) yakni:

$$
\begin{gathered}
\mathrm{Y}=\mathrm{C}+\mathrm{I}+\mathrm{G}+(\mathrm{X}-\mathrm{M}) \\
\mathrm{Y}=\mathrm{GDP}
\end{gathered}
$$

Dari persamaan di atas dapat diketahui bahwa investasi berkorelasi positif dengan GDP, ketika investasi naik maka GDP naik, begitu pula sebaliknya.

Dalam sidang kabinet paripurna yang dihadiri Wakil Presiden Jusuf Kalla dan para Menteri anggota Kabinet Kerja yang digelar di Istana Merdeka pada Selasa, 29 Agustus 2017, Presiden Jokowi juga menekankan bahwa investasi merupakan salah satu kunci pertumbuhan ekonomi di Indonesia (Himawan \& Tanjung, 2017). Oleh karena itu, pemerintah sedang gencargencarnya melakukan berbagai program dan kegiatan untuk meningkatkan investasi di Indonesia. Investasi yang sedang digencarkan lebih difokuskan pada instrumen saham dan sukuk atau obligasi yang diupayakan dapat menjangkau seluruh kalangan masyarakat. Setiap instrumen dijalankan oleh berbagai pihak yang berbeda namun berada dalam satu wadah pengawasan yang sama yakni Otoritas Jasa Keuangan (OJK). Sedangkan lembaga yang mewadahi kegiatan investasi adalah Bursa Efek Indonesia (BEI) di mana investasi yang dikembangkan oleh pemerintah berbentuk efek. Bersama dengan PT Kustodian Sentral Efek Indonesia (KSEI) serta Kliring Penjaminan Efek Indonesia (KPEI) dan berada pada pengawasan dari OJK, BEI meluncurkan sebuah program kampanye untuk meningkatkan minat masyarakat dalam berinvestasi utamanya pada instrumen saham di pasar modal yang kemudian diharapkan menjadikan investor rutin menanamkan investasi di pasar modal. Hal ini secara tidak langsung akan meningkatkan investor aktif di Indonesia, mengingat sampai tahun 2015 jumlah investor aktif masih sebesar 37\% dari seluruh investor di pasar modal yang berjumlah 427.068 SID (Destrianita, 2015). Program tersebut dikenal dengan Yuk Nabung Saham. 


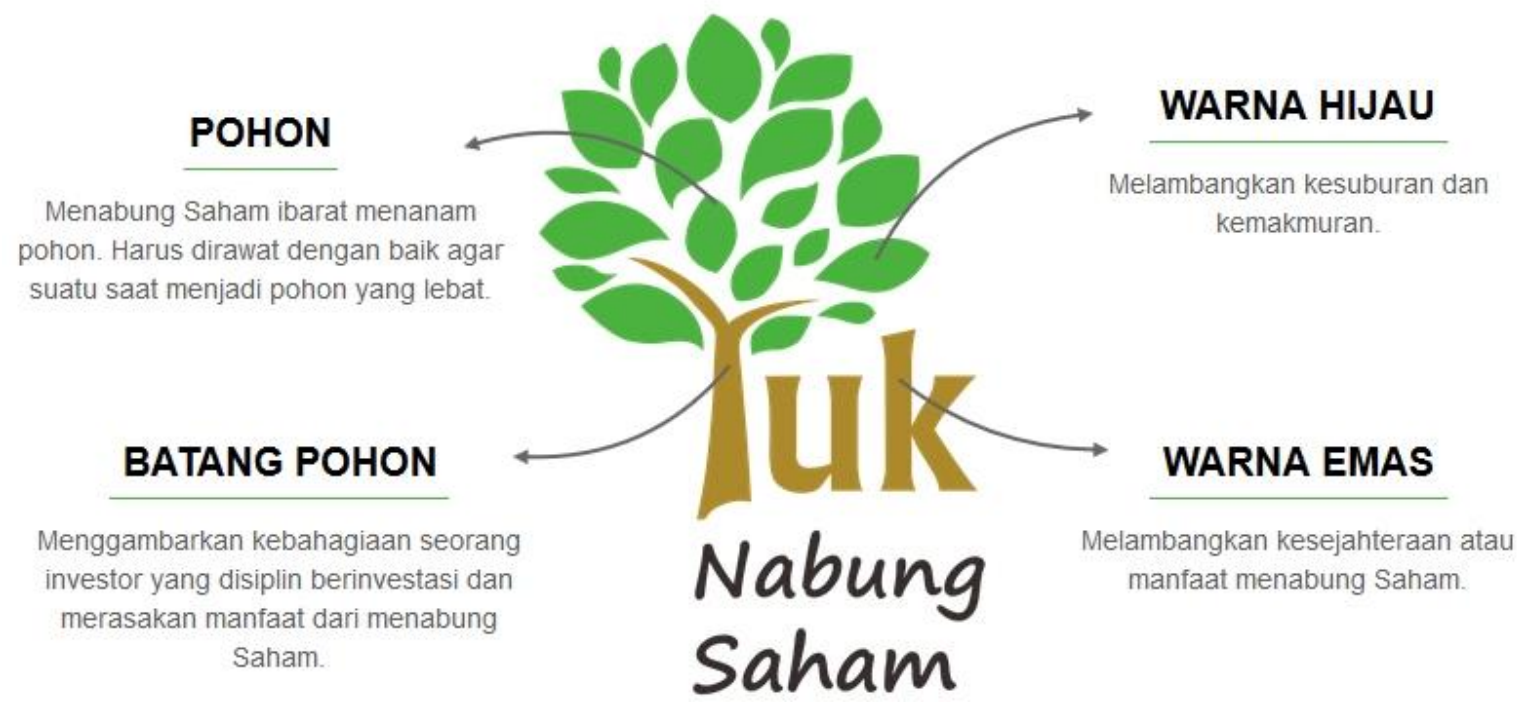

Gambar 1. Logo Program Yuk Nabung Saham

Sumber gambar: yuknabungsaham.idx.co.id

Yuk Nabung Saham menjadi salah satu langkah pemerintah melalui BEI untuk meningkatkan minat masyarakat berinvestasi dengan rutin, mengingat program ini memiliki mekanisme setoran dana investasi seperti tabungan yakni sebesar Rp 100.000/bulan. Sehingga diharapkan masyarakat juga tidak merasa keberatan. Program ini sudah menunjukkan hasil yang menggembirakan, pasalnya pasca peluncurannya, literasi keuangan pasar modal naik ke angka 4,4\% yang sebelumnya hanya 3,8\%. Selain itu tingkat utilitas produk pasar modal atau inklusi keuangan naik dari $0,11 \%$ menjadi 1,25\%, hal ini disampaikan oleh Direktur Pengembangan BEI, Nicky Hogan saat Sosialisai 'Yuk Nabung Saham' di BEI. Selain itu, investasi pada Yuk Nabung Saham di pasar modal sudah sesuai dengan syariah. Ditinjau dari barangnya, investasi pada saham sudah sesuai prinsip syariah di pasar modal karena berlandaskan akad Syirkah Al Musahamah (yuk nabung saham. idx. co. id). Oleh sebab itu calon investor tidak perlu ragu, apalagi sekarang sudah disediakan saham yang syariah yang terkumpul dalam Daftar Efek Syariah.

Minimnya literasi dan inklusi pasar modal di Indonesia, serta investor yang masih didominasi Warga Negara Asing (WNA) serta munculnya program pemerintah yang luar biasa perlu mendapat dukungan dan tindakan dari berbagai pihak. Keresahan dan peluang tersebut, menjadikan peneliti untuk merumuskan sinergi antar berbagai pihak terkait yang dapat meningkatkan literasi dan inklusi pasar modal, instrumen saham pada khususnya. Melalui model penta helix peneliti mencoba menawarkan rumusan konsep untuk meningkatkan literasi keuangan pasar modal serta menjadikan masyarakat sadar akan pentingnya investasi kemudian masyarakat akan aktif untuk berinvestasi. Peneliti berharap penelitian ini dapat menjadi salah satu bahan 158| IQTISHODUNA Vol. 15 No. 2 Tahun 2019 http://ejournal.uin-malang.ac.id/index.php/ekonomi 
referensi pemerintah untuk merumuskan program yang dapat melingkupi stakeholder yang berkepentingan seperti yang dirumuskan dalam model penta helix.

\section{Kajian Pustaka}

Terdapat beberapa teori yang digunakan untuk melakukan analisa dalam penawaran program ini.

\section{Penta Helix}

Model Penta helix (Lindmark, Sturesson \& Roos, 2009) adalah pengembangan dari model Triple Helix dengan melibatkan berbagai elemen masyarakat atau lembaga nirlaba untuk mewujudkan inovasi. Model ini merupakan model pengembangan sosial-ekonomi melalui kolaborasi antara lima sektor yang memiliki peran berbeda. Keberhasilan model ini dinilai dengan adanya sinergi dan komitmen yang kuat antar pemangku kepentingan dalam menjalankan kolaborasi. Dalam model Penta helix peran akademisi adalah sebagai konseptor dengan melakukan standarisasi proses bisnis serta sertifikasi produk dan ketrampilan pada sumber daya manusia. Bisnis berperan sebagai enabler yang menghadirkan infrastruktur TIK, dengan mendukung perubahan pada sumber daya manusia, proses bisnis dan produk yang dihasilkan ke era digital. Komunitas berperan sebagai akselerator sebagai sarana untuk memperlancar adopsi proses bisnis ke era digital dan sebagai penghubung antar pemangku kepentingan. Pemerintah berperan sebagai regulator yang memiliki regulasi dan mengkoordinasi seluruh pemangku kepentingan. Media berperan expander untuk mendukung publikasi dalam promosi dan informasi.

\section{Yuk Nabung Saham}

Yuk Nabung Saham (YNS) merupakan kampanye untuk mengajak masyarakat sebagai calon investor untuk berinvestasi di pasar modal dengan membeli saham secara rutin dan berkala (yuk nabung saham .idx. co. id) (Riyadi, 2016). Program ini melibatkan empat stakeholder yaitu BEI, KSEI, KPEI dan OJK sebagai pengawas. Skema program ini sama dengan menabung, hanya bentuk tabungannya saham yang disetor setiap bulan sebesar $\mathrm{Rp}$ 100.000 dengan diawali pembukaan rekening dana investor dan rekening efek. Operasional transaksi saham dan pembukaan rekening dilakukan oleh perusahaan sekuritas. Di mana transaksi dapat dilakukan secara offline atau online, tergantung dari masing-masing perusahaan sekuritas. Selain itu, nominal setoran awal disesuaikan dengan perusahaan sekuritas yang dipilih. 
Muhammad Al Faridho Awwal, Dewi Wahyu Setyo Rini

Adapun dokumen persyaratan pembukaan rekening efek antara lain:

1. Fotokopi KTP

2. Fotokopi NPWP (jika ada)

3. Fotokopi halaman depan buku tabungan

4. Materai Rp 6.000 minimal dua buah

Perusahaan sekuritas atau perusahaan efek adalah perusahaan yang telah mendapat izin usaha dan diawasi oleh Otoritas Jasa Keuangan untuk dapat melakukan kegiatan sebagai perantara perdagangan efek (broker). Rekening Efek adalah rekening transaksi jual beli efek yang dibayar/diterima secara tunai pada waktu jatuh tempo. Rekening dana investor adalah rekening di bank atas nama investor yang terpisah dari rekening sekuritas (atas nama sekuritas) yang digunakan untuk keperluan transaksi jual beli saham oleh investor.

\section{Metodologi Penelitian}

Penulisan penelitian menggunakan metode library research, di mana permasalahan didasarkan pada data-data yang terdapat pada literatur atau dokumen. Disebut penelitian kepustakaan karena data-data atau bahan-bahan yang diperlukan dalam menyelesaikan penelitian tersebut berasal dari perpustakaan baik berupa buku, ensiklopedia, kamus, jurnal, dokumen, majalah dan lain sebagainya (Hadi, 1990). Kemudian data tersebut di analisa untuk mendapatkan sebuah kesimpulan. Data dianalisis dengan metode kualitatif yang bersifat deskriptif. Namun, peneliti mencoba menyajikan analisa data secara kuantitatif melalui uji coba terkait tingkat korelasi dan pengaruh investasi terhadap pertumbuhan ekonomi. Data yang digunakan berupa data time series dari tahun 2010 - 2017. Variabel independen yang digunakan indeks peningkatan investasi sedangkan variabel dependennya pertumbuhan ekonomi di Indonesia. Untuk menguji tingkat pengaruh variabel independen terhadap variabel dependen dalam jangka panjang dan jangka pendek digunakan analisis Error Correction Model (ECM).

Pendekatan Eror Correction Model merupakan model yang digunakan untuk mengoreksi persamaan regresi di antara variablel-variabel yang secara individual tidak stasioner agar kembali ke nilai equilibriumnya di jangka panjang (Ajija, 2011). ECM sering digunakan dalam analisis data timer series bahkan diunggulkan dalam analisis karena ECM dalam menganalisis fenomena ekonomi dalam jangka panjang (Insukrindo, 1999). Dalam pengujian data menggunakan model ECM, data tersebut dianalisis menggunakan statistik deskriptif, dilanjutkan uji stasioner kemudian dilakukan uji kointegrasi. Ketika data time series tidak stasioner maka akan menghasilkan spurious regression di mana hasil regresi menunjukkan koefisien regresi yang signifikan secara statistik dan nilai koefisien 
determinasi yang tinggi namun ada hubungan antar variabel dalam model tidak saling berhubungan (Widarjono, 2013).

\section{Model Error Correction Model Engle-Grenger}

1. Estimasi Persamaan Jangka Panjang

Apabila $Y_{t}$ dan $X_{t}$ terkointegrasi maka persamaan regresinya $Y_{t}=\alpha+$ $\beta X_{t}+\varepsilon_{t}$, di mana nilai $\beta$ merupakan koefisien diinterpretasikan sebagai long run multiplier yang mengukur jangka panjang secara persamaan pengaruh variabel $X_{t}$ terhadap variabel $Y_{t}$. Dengan adanya uji kointegrasi, hubungan ekuilibrium jangka panjang dari variabel-variabel yang tidak stasioner dapat diamati. Dari persamaan kointegrasi di atas, berikut persamaan jangka panjang persamaan kointegrasi untuk penelitian ini:

\section{Pertumbuhan_Ekonomi $_{t}=\beta_{0}+\beta_{1}(\text { Tingkat_Investasi })_{t}+\varepsilon_{t}$}

Adapun keterangan simbol t menyatakan tren waktu, $\beta$ sebagai koefisien tingkat pengaruh variabel independen terhadap variabel dependen dan $\varepsilon$ merupakan variabel gangguan dari persamaan regresi.

\section{Estimasi Persamaan Jangka Pendek}

Dalam jangka panjang ketika variabel-variabel telah terkointegrasi dapat dikatakan variabel memiliki keseimbangan atau hubungan. Tetapi tidak untuk jangka pendek, keadaan tersebut memungkinkan terjadinya ketidakseimbangan (disequilibrium). Hal ini yang terkadang sering dialami pelaku ekonomi. Di mana hasil secara statistik tidak sesuai dengan kenyataan. Oleh sebab itu untuk menyeimbangkannya diperlukan penyesuaian (adjustment). Model koreksi kesalahan diestimasi dengan memasukkan variabel penyesuaian untuk mengetahui ketidakseimbangan yang terjadi (Widarjono, 2013). Menurut Granger Representation Theorm untuk mengetahui hubungan dari variabel yang terkointegrasi dianalisis menggunakan Error Correction Model (Muhammad, 2014).

Pada penelitian ini dalam melakukan penyesuaian menggunakan mekanisme error correction yang diperkenalkan oleh Sargan dan dipopulerkan oleh Engle dan Granger pada tahun 1987. Model ini juga dikenal dengan model dua langkah. Menurut mereka, ketika Yt dan Xt tidak stasioner tetapi berkointegrasi maka hubungan jangka pendek kedua variabel tersebut dapat ditulis dengan persamaan sebagai berikut (Widarjono, 2013): 
Muhammad Al Faridho Awwal, Dewi Wahyu Setyo Rini

$$
\begin{gathered}
\Delta Y=\alpha+\alpha_{1} \Delta X_{t}+\alpha_{2} R E S_{t}+\varepsilon_{t} \\
R E S_{t}=\left(Y_{t-1}-\beta_{0}-\beta_{1} X_{t-1}\right)
\end{gathered}
$$

Dari persamaan di atas dapat dituliskan persamaan untuk penelitian ini sebagai berikut:

$$
\Delta \text { Pertumbuhan_Ekonomi } t_{t}=\alpha_{0}+\alpha_{1} \Delta \text { Tingkat_Investasi }{ }_{t}+\alpha_{2} \text { RES }_{t}+\varepsilon_{t}
$$

Data yang digunakan berupa data time series tahunan yakni dari tahun 2010 - 2017 yang diambil dari Badan Pusat Statistik dan Laporan Kegiatan Penanaman Modal (LKPM) tahun 2017.

\section{Metode Wawancara}

Data wawancara merupakan data primer yang digunakan sebagai data penguat dari penelitian yang dilakukan. Wawancara dilakukan kepada beberapa stakeholder yang berhubungan langsung dengan penelitian, antara lain Ketua Kelompok Studi Pasar Modal (KSPM) Universitas Islam Negeri Sunan Kalijaga dan Galeri Investasi Bursa Efek Indonesia di Universitas Negeri Semarang (UNNES).

\section{Hasil Dan Pembahasan}

Hasil Analisis Data Peran Investasi PMDN Terhadap Pertumbuhan Ekonomi di Indonesia dalam Jangka Panjang dan Jangka Pendek (Metode Error Correction Model Engle-Granger)

1. Model 1

Hasil estimasi persamaan jangka panjang ditunjukkan pada tabel 1, di ketahui nilai koefisien determinasi yang disesuaikan (Adjusted $R$ Squared) sebesar 0.8397 artinya bahwa kemampuan variabel independen dalam menjelaskan perubahan variabel dependen sebesar $83.97 \%$ sedangkan sisanya sebesar $26.03 \%$ dijelaskan oleh variabel lain. Estimasi parameter pengaruh dapat dilihat dari dua kolom yakni kolom t-statistik dan kolom probabilitas. Untuk kolom t-statistik dikatakan memiliki pengaruh ketika nilai t-statistik lebih besar dari nilai t-tabel, sedangkan dari kolom Prob. dikatakan berpengaruh ketika nilainya kurang dari nilai alfa $(\alpha)$ yakni 0.05. Dari hasil estimasi berikut diketahui nilai Prob (F-statistik) Sebesar 0.000856 sehingga disimpulkan bahwa perubahan variabel tingkat investasi mempengaruhi secara signifikan terhadap perubahan variabel pertumbuhan ekonomi di Indonesia. Mengingat variabel independen yang digunakan hanya satu sehingga persamaan regresi yang digunakan persamaan sederhana, maka hasil uji f-statistik sama dengan hasil uji t-statistik. 
Tabel 1. Hasil Estimasi Persamaan Jangka Panjang

\begin{tabular}{lrrrr}
\hline \hline \multicolumn{1}{c}{ Variable } & Coefficient & Std. Error & t-Statistic & Prob. \\
\hline \hline LNTINGKAT_INVES' & -0.010239 & 0.001668 & -6.138308 & 0.0009 \\
$\quad$ C & 0.175604 & 0.019671 & 8.927281 & 0.0001 \\
\hline \hline Adjusted R- & & & \\
squared & 0.839739 & & \\
F-statistic & 37.67883 & & \\
Prob(F-statistic) & 0.000856 & & \\
\hline \hline
\end{tabular}

\section{Model 2}

Hasil estimasi persamaan jangka panjang ditunjukkan pada Tabel 1, di ketahui nilai koefisien determinasi yang disesuaikan (Adjusted $R$ Squared) sebesar 0.9993 artinya bahwa kemampuan variabel independen dalam menjelaskan perubahan variabel dependen sebesar $99.93 \%$ sedangkan sisanya sebesar $0.07 \%$ dijelaskan oleh variabel lain. Estimasi parameter pengaruh dapat dilihat dari dua kolom yakni kolom t-statistik dan kolom probabilitas. Untuk kolom t-statistik dikatakan memiliki pengaruh ketika nilai t-statistik lebih besar dari nilai t-tabel, sedangkan dari kolom Prob. dikatakan berpengaruh ketika nilainya kurang dari nilai alfa $(\alpha)$ yakni 0.05 . Dari hasil estimasi berikut diketahui nilai Prob (F-statistic) Sebesar 0.015513 sehingga disimpulkan bahwa perubahan variabel tingkat investasi mempengaruhi secara signifikan terhadap perubahan variabel pertumbuhan ekonomi di Indonesia. Angka penyesuaian untuk persamaan jangka pendek disimbolkan dengan RES, di mana hasil olah data berikut menunjukkan nilai RES sebesar 0.0120 yang artinya penyesuaian telah menyebutkan bahwa terdapat pengaruh dari perubahan tingkat investasi terhadap pertumbuhan ekonomi. 
Muhammad Al Faridho Awwal, Dewi Wahyu Setyo Rini

Tabel 2. Hasil Estimasi Persamaan Jangka Pendek

\begin{tabular}{crrrr}
\hline \hline Variable & Coefficient & Std. Error t-Statistic & Prob. \\
\hline \hline LN TINGKAT_ & & & & \\
INVESTASI & 0.003079 & $5.96 \mathrm{E}-05$ & 51.70323 & 0.0123 \\
RES & -0.326093 & 0.006170 & -52.85479 & 0.0120 \\
C & 0.012395 & 0.000727 & 17.05063 & 0.0373 \\
\hline \hline Adjusted R-squared & 0.999278 & & & \\
F-statistic & 2077.138 & & & \\
Prob(F-statistic) & 0.015513 & & & \\
\hline \hline
\end{tabular}

\section{Stakeholder pada Model Penta helix dalam Mengedukasikan Program Yuk Nabung Saham Sebagai Upaya Peningkatan Sadar Investasi Masyarakat.}

Terdapat lima stakeholder yang penulis rumuskan terkait upaya edukasi Yuk Nabung Saham sebagai program peningkatan sadar investasi masyarakat pada model penta helix antara lain akademisi, bisnis, komunitas, pemerintah dan media.

1. Akademisi

Akademisi pada model penta helix berperan sebagai konseptor. Dalam hal ini akademisi merupakan bagian yang memahami pengetahuan dengan segala konsep, teori-teori terbaru dan relevan yang berkaitan dengan investasi dan pasar modal. Pada model penta helix, akademisi berperan melakukan standarisasi jenis teori yang relevan untuk kemudian diedukasikan ke masyarakat terutama masyarakat awam. Peran edukasi kepada masyarakat akan lebih banyak dilakukan oleh komunitas yang berada dalam pendampingan akademisi. Akademisi yang dimaksud dalam model ini adalah kampus yang memiliki komunitas yang fokus dalam pengkajian pasar modal. Kampus memiliki peran penting untuk mengedukasi komunitas terkait semua teori dan pemahaman terkait investasi di pasar modal, selain itu kampus juga sebagai pendamping dan coordinator bagi komunitas tersebut.

Dalam research ini peneliti memosisikan kampus Universitas Islam Negeri Sunan Kalijaga Yogyakarta lebih khususnya Fakultas Ekonomi dan Bisnis Islam (FEBI) sebagai objek akademisi. Di mana FEBI sudah memiliki lembaga naungan komunitas yang fokus di bidang pasar modal. Dalam hal edukasi, terdapat dosen-dosen pembina dan narasumber-narasumber lain di luar wilayah kampus baik dari peneliti maupun praktisi yang rutin mengisi kajian dan diskusi kepada anggota komunitas bahkan seluruh mahasiswa di 
fakultas. Hal tersebut sebagai upaya edukasi kepada FEBI terkait investasi dalam pasar modal. Terkhusus dalam komunitas, terdapat pembinaan secara khusus yang diterapkan, disinilah penerapan standarisasi silabus teori dan pemahaman apa saja yang harus diedukasikan kepada masyarakat. Mengingat masyarakat tidaklah sama dengan mahasiswa maupun pelajar, masyarakat bersifat kompleks dan multikultural sehingga setiap anggota di komunitas harus memiliki pemahaman yang baik sehingga ketika mengedukasikan ke masyarakat tidak menimbulkan kesalahpahaman.

\section{Bisnis}

Bisnis pada model penta helix berperan sebagai enabler, yakni pihak atau entitas yang melaksanakan proses bisnis dalam pencapaian suatu tujuan dan mempertahankan serta meningkatkan pertumbuhan yang berkelanjutan. Bisnis berperan menyediakan layanan yang langsung terhubung dengan pelaksana program upaya peningkatan sadar investasi kepada masyarakat. Peran bisnis yang dimaksud pada model penta helix ini adalah perusahaan sekuritas. Adapun yang dimaksud perusahaan sekuritas merupakan perusahaan yang mendapat izin dari Pengawas Pasar Modal untuk melakukan penjaminan emisi efek, perantara perdagangan efek atau manajer investasi dalam transaksi efek. Peran utamanya perusahaan efek sebagai perantara atau broker antara Bursa Efek Indonesia (BEI) dan investor dalam melakukan perdagangan efek. Jadi, ketika investor ingin melakukan jual beli efek dapat melalui perusahaan sekuritas yang sudah terdaftar di Bursa Efek Indonesia, sehingga tidak harus berkunjung ke BEI.

Perusahaan sekuritas memiliki peran penting dalam peningkatan jumlah investor dalam perdagangan efek. Ketika perusahaan sekuritas belum tersebar hal ini menjadi kendala tersendiri bagi calon investor yang ingin berinvestasi, terlepas dari hambatan terkait literasi. Oleh sebab itu, dalam model penta helix peneliti mencoba menawarkan program sebagai upaya perluasan akses melalui penambahan jaringan perusahaan sekuritas tanpa harus membuka cabang kantor. Dalam pelaksanaan program tersebut, peran bisnis dikolaborasikan dengan komunitas sebagai edukator kepada masyarakat.

\section{Komunitas}

Komunitas dalam model penta helix berperan sebagai akselerator. Komunitas yang dimaksud dalam sinergi riset ini yaitu sekelompok orang yang fokus belajar mengenai pasar modal dan memiliki visi dan misi dalam peningkatan inklusi keuangan pasar modal melalui edukasi kepada lingkungan sekitar. Komunitas yang berperan dalam model penta helix merupakan komunitas mahasiswa yang berada dalam naungan kampus. Dalam riset ini peneliti menelaah lebih jauh terkait KSPM yang ada di UIN Sunan Kalijaga Yogyakarta. Intan Sholeha selaku Ketua KSPM UIN Sunan 
Kalijaga menyebutkan bahwa KSPM merupakan Kelompok Study Pasar Modal yang terdiri dari beberapa orang yang memiliki minat terhadap industri terkait dengan investasi dalam hal ini pasar modal. Sebelumnya, kelompok ini hampir mati karena peminatnya yang semakin sedikit. Namun, di tahun ini perkembangan KSPM begitu luar biasa, hal ini terjadi tepatnya setelah KSPM resmi menjadi bagian lembaga kegiatan fakultas di UIN Sunan Kalijaga. Rintisan awal KSPM memang mengedukasikan kepada anggota terkait pemahaman mengenai pasar modal, hal tersebut biasanya dikaji dalam diskusi dan kajian. Selain diskusi dan kajian terdapat salah satu program interaksi langsung kepada industri yang sudah bekerja sama dengan kampus.

Dalam wawancara yang dilakukan, Intan Sholeha juga mengatakan bahwa KSPM beberapa kali ikut membantu seminar BEI untuk mempromosikan investasi di pasar modal utamanya terkait program Yuk Nabung Saham kepada pelajar dan mahasiswa di Yogyakarta. Seminar ini sebagai wujud kerja sama antara BEI, fakultas dan KSPM sendiri. Dari sini selain membantu mempersiapkan seminar, anggota KSPM juga langsung dilatih untuk menjadi investor dan pelaku industri yang profesional. Sehingga anggota KSPM tidak hanya paham akan teori, namun juga mengerti bagaimana operasional pasar modal dan BEI.

Walaupun baru setengah tahun komunitas ini sudah terbilang aktif dan menghasilkan anggota-anggota yang sudah paham secara teori dan terjun langsung menjadi investor. Selain itu, sinergitas KSPM dan BEI tidak hanya pada agenda membantu seminar semata namun KSPM juga dituntut untuk memiliki agenda rutin berkunjung ke BEI. Hal ini bertujuan untuk memperkenalkan kepada KSPM terkait bagian-bagian di BEI, juga untuk melatih anggota terjun langsung di lingkungan industri yang ditekuni. Dengan bekal ini, perlu kiranya ada perluasan akses KSPM dalam membantu BEI untuk mempromosikan investasi di BEI salah satunya program Yuk Nabung Saham sebagai wujud pengabdian terhadap pemerintah dalam mewujudkan Indonesia sebagai negara dengan tingkat investasi yang tinggi. Penawaran dalam model penta helix ini, KSPM memiliki peran sebagai sumber informasi dan edukasi langsung kepada masyarakat. Bersama dengan perusahaan sekuritas, KSPM melakukan edukasi langsung ke masyarakat untuk memperkenalkan investasi dan potensi investasi bagi negara Indonesia. Bekal teori, praktik, pengalaman yang sudah diterima anggota KSPM menjadi modal yang tepat dalam menyalurkannya dalam lingkup yang lebih luas.

4. Pemerintah

Pemerintah pada model penta helix berperan sebagai regulator sekaligus kontroler. Pemerintah berperan mengeluarkan kebijakan terkait peningkatan sadar investasi kepada masyarakat (Slamet dkk, 2017). Dalam hal ini melibatkan semua jenis kegiatan perencanaan, pelaksanaan, 
pemantauan, pengendalian, promosi, alokasi keuangan, perizinan, program, Undang-undang, pengembangan dan pengetahuan, kebijakan inovasi publik, dukungan untuk jaringan inovasi dan kemitraan publik swasta (Nurmalia \& Zaenuri, 2018). Dalam model ini peran pemerintah oleh Otoritas Jasa Keuangan (OJK) dan Bursa Efek Indonesia. OJK sebagai pembuat kebijakan dan pengawasan terhadap perkembangan segala hal yang berkaitan dengan keuangan di Indonesia. Sedangkan, BEI merupakan lembaga pemerintahan yang berfungsi sebagai wadah operasional perdagangan efek. Pemasaran terkait pentingnya investasi menjadi sebuah kebijakan bagi stakeholder yang bersangkutan, tidak lain untuk 0JK. Salah satu contoh 0JK dalam menawarkan investasi kepada masyarakat salah satunya dilakukan ketika memberikan seminar mengenai investasi di Pasar Modal Indonesia kepada puluhan karyawan PT Pembangunan Jaya Ancol Tbk (PJAA). Anggota Dewan Komisioner OJK Bidang Edukasi dan Perlindungan Konsumen Kusumaningtuti S. Soetiono memberikan tips agar berinvestasi yang aman. Yaitu mengenali saham apa yang akan kita beli dan jangan terpengaruh oleh orang lain dalam membeli saham. Direktur Properti dan Keuangan Pembangunan Jaya Ancol, Arif Nugroho, di Hotel Putri Duyung Ancol, Jakarta, Kamis (26/5/2016) juga mengharapkan dengan adanya kegiatan ini karyawan PT Pembangunan Jaya Ancol akan lebih membuka mata tentang investasi agar lebih memahami agar banyak yang mau jadi investor. OJK menawarkan program investasi dengan skema menabung dengan modal yang kecil. Hal ini dikarenakan pengembangan pasar modal dan investasi di Indonesia merupakan bagian dari tugas OJK.

Dalam roadmap pasar modal tahun 2015 - 2019 program utamanya yaitu meningkatkan sadar investasi terhadap masyarakat. Sebagai salah satu upaya perwujudan hal tersebut OJK bekerja sama dengan BEI melalui program Yuk Nabung Saham. Jadi memang sudah ada sinergi antara OJK dan BEI terkait peningkatan edukasi dan sadar investasi masyarakat. Selain mendukung dalam hal legalitas dan pengeluaran kebijakan, OJK juga ikut mempromosikan program Yuk Nabung Saham melalui seminar bersama Bursa Efek Indonesia. OJK juga berperan melakukan koordinasi terhadap semua pihak yang berkepentingan dalam pengembangan program ini. Peran BEI dalam peningkatan sadar investasi masyarakat tidak hanya pada pengembangan di program Yuk Nabung Saham, namun BEI juga membuka Sekolah Pasar Modal yang dapat diikuti oleh masyarakat. Dengan adanya hal ini harapannya dapat menarik minat masyarakat sehingga kemudian ikut berpartisipasi sebagai investor di BEI. 
Muhammad Al Faridho Awwal, Dewi Wahyu Setyo Rini

5. Media

Media dalam model penta helix berperan sebagai expender. Di mana media berperan dalam bidang promosi dan pemasaran. Indonesia merupakan negara dengan penduduk yang selalu memanfaatkan media sebagai salah satu alternatif pemenuhan kebutuhan secara cepat. Perkembangan peran media terkait edukasi mengenai investasi di pasar modal sudah dilakukan melalui website, media sosial, artikel dan lainnya. Dalam pelaksanaan prosedur investasi juga sudah banyak yang dilakukan secara online. Namun, tidak jarang perusahaan sekuritas yang belum memiliki aplikasi secara online. Terkait program Yuk Nabung Saham sudah terdapat website sebagai media informasi kepada masyarakat. Namun sebenarnya media secara online ini belum mampu diakses semua kalangan, sehingga perlu adanya media lain yang bisa mengakses semua kalangan. Seperti halnya program khusus offline yang BEI bagikan kepada lembaga pemerintahan di bawahnya, seperti ke pemerintah daerah bagian edukasi keuangan. Dengan demikian, media offline tersebut dapat tersalurkan sampai masyarakat bawah. Berikut web resmi program Yuk Nabung Saham sebagai media informasi ke masyarakat.

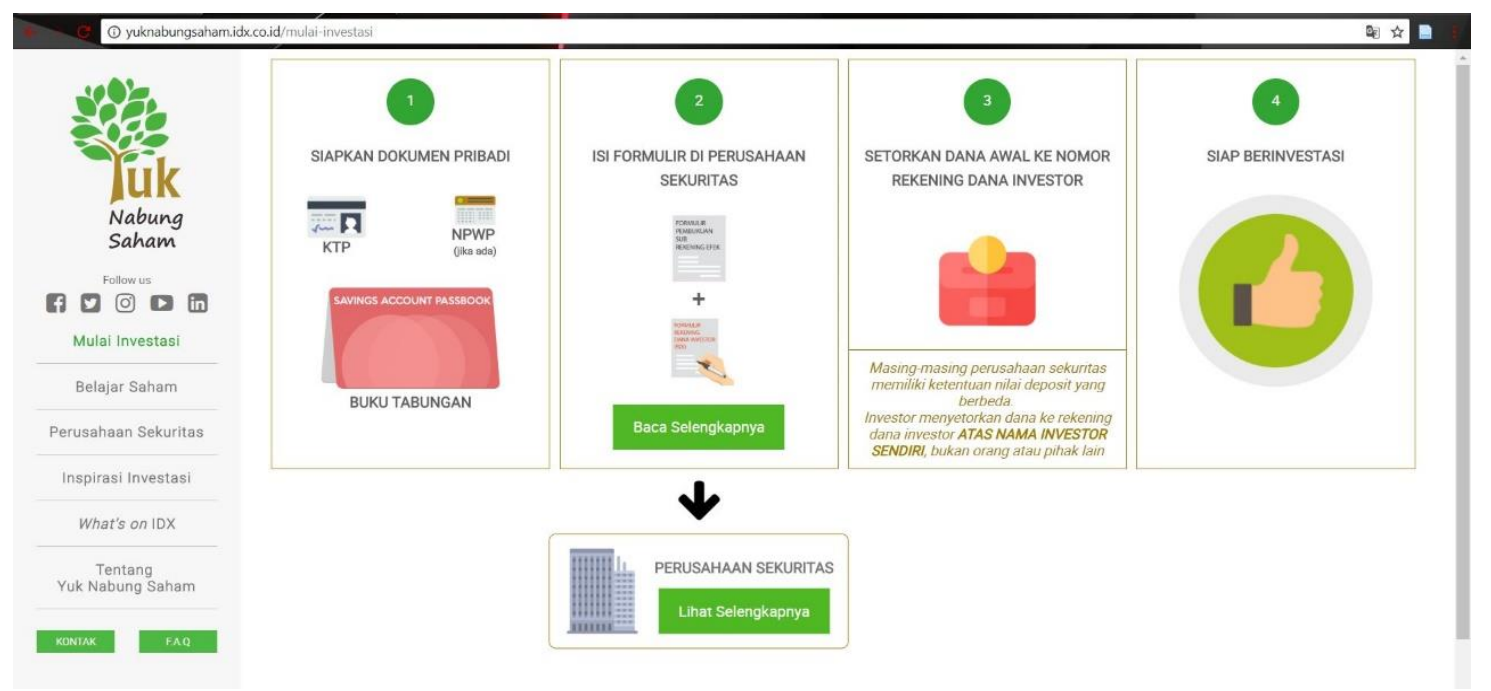

Gambar 2. Web Resmi Program Yuk Nabung Saham

Sumber gambar: http://yuknabungsaham.BEI.co.id/mulai-investasi

\section{Model Penta helix Pada Pengembangan Program Yuk Nabung Saham Sebagai Upaya Peningkatan Masyarakat yang Sadar Investasi}

Dalam pelaksaan segala sesuatu yang akan dicapai terdapat pihakpihak yang berkepentingan dalam melaksanakannya. Pihak yang berkepentingan diartikan sebagai individu atau badan yang mempengaruhi atau dipengaruhi oleh satu pencapaian tujuan organisasi (Muhyi et al., 2017).

Berdasarkan telaah literatur terhadap objek penelitian, terdapat lima 168| IQTISHODUNA Vol. 15 No. 2 Tahun 2019

http://ejournal.uin-malang.ac.id/index.php/ekonomi 
stakeholder yang berkepentingan dalam pengembangan program tersebut sehingga model yang cocok untuk menyinergikan kelima stakeholder menggunakan model penta helix. Model penta helix merupakan kolaborasi antara akademisi, bisnis, komunitas, pemerintah dan media.

Sebelum adanya konsep rekomendasi menggunakan model penta helix ini, program Yuk Nabung Saham baru dijalankan oleh stakeholder tertentu dengan sinergi yang belum maksimal. Menggunakan pengembangan dengan konsep sebelumnya sudah memberikan dampak positif terkait jumlah investor di Indonesia. Oleh karena itu, diharapkan dengan adanya sinergi kelima stakeholder dapat meningkatkan jumlah investor secara lebih signifikan. Berikut konsep rekomendasi mekanisme pelaksanaan pemasaran program Yuk Nabung Saham di masyarakat umum.

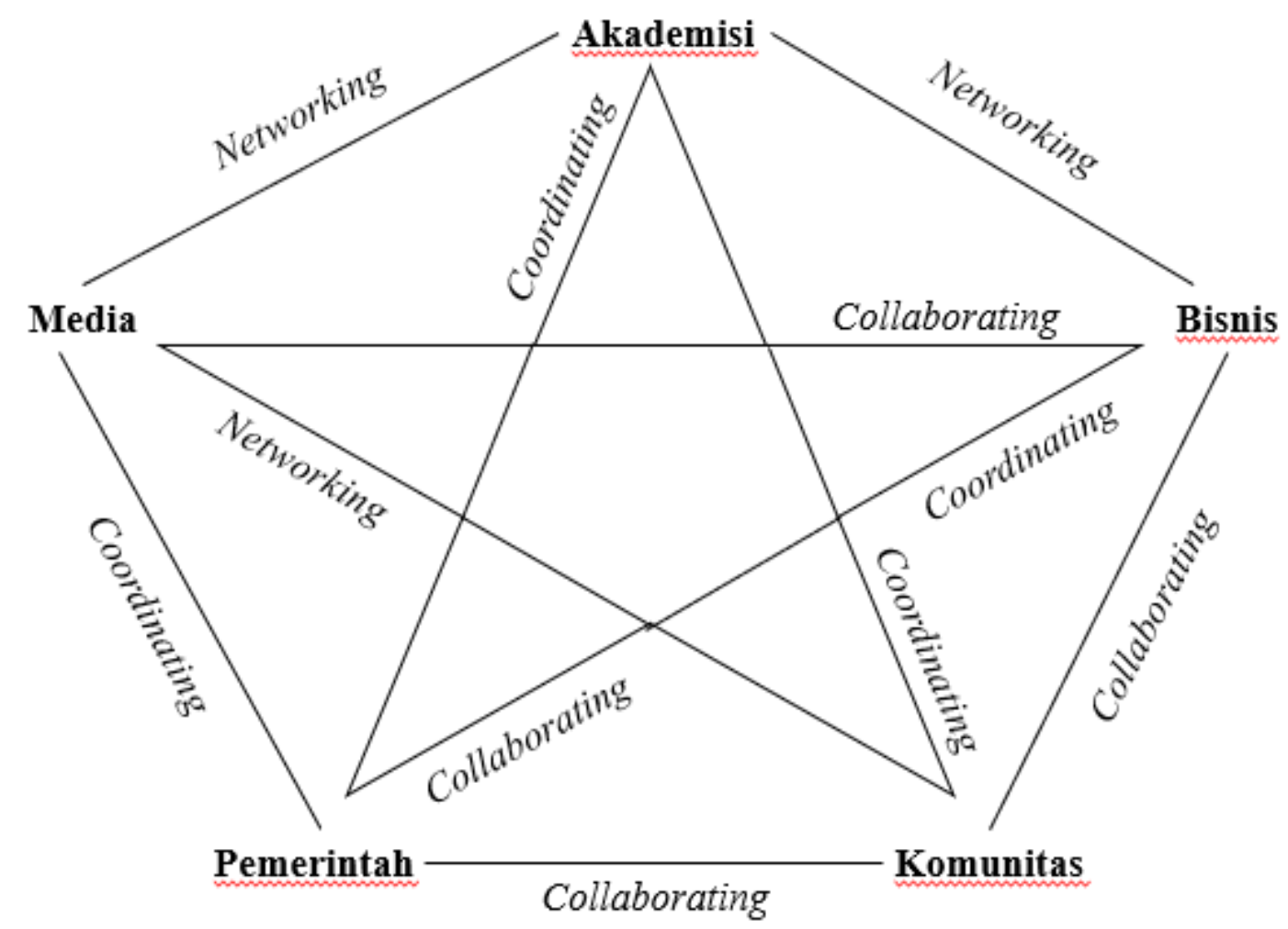

\section{Gambar 3. Konsep Rekomendasi Sinergi Stakeholder dengan Model Penta helix Untuk Pengembangan Program Yuk Nabung Saham sebagai Upaya Peningkatan Investasi di Indonesia}

Sumber: Nurmalia \& Zaenuri, 2018

Jenis hubungan kerja sama antar stakeholder dalam menggapai satu tujuan tidaklah sama. Kolaborasi merupakan kerja sama tertinggi dari beberapa jenis kerja sama. Di mana kolaborasi merupakan kerja sama secara 
resmi dengan bertukar informasi untuk saling menguntungkan, mengubah aktivitas, berbagi sumber daya dan meningkatkan kapasitas orang lain untuk mencapai tujuan bersama (Nurmalia \& Zaenuri, 2018). Selain itu kerja sama kolaborasi merupakan hubungan kerja sama yang memiliki kepercayaan tinggi antar stakeholder karena terdapat aktivitas berbagi sumber daya, risiko, tanggung jawab dan penghargaan. Oleh karena itu, tidak semua hubungan menggunakan skema kolaborasi, karena dapat menimbulkan hasil yang tidak optimal. Dengan demikian, penentuan bentuk kerja sama disesuaikan dengan kebutuhan yang diperlukan. Berikut pemaparan jenis hubungan antar kelima stakeholder:

\section{Pemerintah dengan Akademisi}

Jenis hubungan antara pemerintah dan akademisi dalam bagan rekomendasi di atas yakni collaborating. Menurut Roberts (2004) hubungan dikatakan collaborating ketika terdapat komitmen waktu intensif, tingkat kepercayaan tinggi, serta ada pembagian risiko dan tanggung jawab. Dalam perkembangannya, hubungan kolaborasi yang tercipta antara pemerintah dan akademisi sudah terwujud dalam adanya kerja sama berbentuk MoU. Seperti salah satunya kampus UIN Sunan Kalijaga dan Universitas Negeri Semarang yang secara resmi sudah memiliki MoU dengan BEI. Ketua KSPM UNNES, Hendru menyebutkan sudah terdapat kerja sama resmi dari fakultas dengan BEI dan perusahaan sekuritas. Hal tersebut diwujudkan dalam keikutsertaan BEI memfasilitasi pengembangan pasar modal di UNNES, seperti komputer, aplikasi trading, galeri investasi dan segala hal yang berhubungan dengan pengembangan pasar modal. Selain itu, BEI juga memudahkan mahasiswa Fakultas Ekonomi UNNES saat membuka rekening saham dengan membebaskan dari pembayaran administrasi.

Hendru juga menjelaskan bahwa selain prasarana, BEI juga sering ikut serta mengisi kegiatan berupa edukasi kepada mahasiswa fakultas ekonomi. Kolaborasi yang begitu matang ini, sedikit demi sedikit dapat menjangkau akses pasar modal ke lingkup mahasiswa apalagi dengan adanya galeri investasi di kampus. Selain BEI, OJK beberapa kali mengisi kajian terkait pasar modal di beberapa kampus salah satunya UIN Sunan Kalijaga. Hubungan kolaborasi ini diharapkan terus ditingkatkan, hingga bisa meluas ke berbagai kampus lainnya. Sehingga pengembangan investasi di pasar modal utamanya program Yuk Nabung Saham di tingkat mahasiswa lebih mudah.

\section{Pemerintah dengan Bisnis}

Pemerintah dengan bisnis memiliki dua hubungan yakni coordinating dan collaborating. Dua jenis hubungan ini terjadi karena peran pemerintah dalam model ini diperankan oleh dua stakeholder yakni BEI dan OJK sedangkan 
bisnis diperankan oleh perusahaan sekuritas. Hubungan OJK dengan perusahaan sekuritas yakni coordinating di mana OJK tidak melakukan hubungan secara langsung untuk terjun mengembangkan program Yuk Nabung Saham, namun OJK melakukan pengawasan serta pemberian kebijakan terkait pelaksanaan dan posisi perusahaan sekuritas. Selain itu, OJK juga berbagi sumber daya seperti informasi terkait hasil penelitian yang dilakukan OJK dalam mengembangkan pasar modal di Indonesia yang nantinya akan menjadi bahan untuk pemasaran investasi. Selain itu, selama ini OJK juga ikut berperan dalam promosi program Yuk Nabung Saham sebagai solusi untuk peningkatan investasi di Indonesia. Kemudian, hubungan pemerintah dengan bisnis antara BEI dengan perusahaan sekuritas yakni collaborating. Di mana dalam hubungan ini terjalin kerja sama untuk saling berbagi risiko, tanggung jawab dan reward. BEI yang berperan sebagai wadah terjadinya transaksi perdagangan efek sedangkan perusahaan sekuritas sebagai mediator tentu hubungan kolaborasi di antara keduanya sangat penting. Tidak hanya bersifat langsung, namun kedua stakeholder ini memiliki hubungan yang terikat. BEI menggandeng perusahaan sekuritas untuk memudahkan pelaksanaan transaksi kepada masyarakat. Hingga tahun 2017 perusahaan sekuritas yang sudah bekerja sama dengan BEI sebanyak 34 dan kedepannya akan terus ditingkatkan.

\section{Pemerintah dengan Media}

Jenis hubungan pemerintah dengan media adalah coordinating yang berarti terdapat hubungan saling berbagai sumber daya minimal namun tetap resmi dan memiliki komitmen waktu yang sedang. Media yang memiliki peran dalam publikasi atau promosi produk serta membagikan informasi kepada masyarakat merupakan bagian dalam berbagi sumber daya minimal namun tetap resmi. Sejak program Yuk Nabung Saham resmi diluncurkan pada tanggal 1 November 2015 publikasi yang sudah dilakukan yakni melalui media website dan media sosial. Oleh karena itu, setelah terjalinnya hubungan ini diharapkan media memiliki peran secara maksimal dalam publikasinya misalnya ketika OJK akan mengadakan sosialisasi atau seminar, media dapat mempublikasikannya baik secara online maupun offline sehingga jangkauan masyarakat bisa meluas. Rekomendasi hubungan yang peneliti tawarkan yaitu terdapat pembagian informasi secara serempak di berbagai media seperti media sosial, koran, majalah dan web resmi. Hal tersebut dapat terlaksana ketika ada koordinasi langsung dari pemerintah kepada media secara baik.

\section{Komunitas dengan Akademisi}

Hubungan yang terjalin antara komunitas dan akademisi adalah coordinating. Dalam model penta helix, komunitas memiliki peran langsung 
bersama bisnis untuk mengembangkan program Yuk Nabung Saham melalui upaya jemput bola. Dengan demikian, komunitas yang merupakan mahasiswa dari kampus tertentu harus mendapatkan jaminan langsung dari kampus sebagai pihak akademisi. Jadi, akademisi berhubungan dengan komunitas dalam garis koordinasi, yakni universitas sebagai penanggung jawab dalam melakukan pendampingan terhadap pelaksanaan program ini serta komunitas melakukan pelaporan terhadap kegiatan yang telah dilaksanakan. Selain bertanggung jawab terhadap pelaksanaan kegiatan ini, akademisi juga berperan untuk mengkoordinasi terkait kegiatan kajian dan diskusi sebagai media penanaman pemahaman pasar modal kepada mahasiswa.

Seperti halnya komunitas pasar modal di Universitas Islam Negeri (UIN) Sunan Kalijaga dan Universitas Negeri Semarang (UNNES) yang sudah menjadi bagian dari Lembaga Kegiatan Mahasiswa Fakultas dan bertanggung jawab langsung kepada fakultas. Selain bertanggung jawab dalam skala besar, KSPM juga mendapat pembinaan langsung dari pembina LKMF yang ditunjuk langsung oleh fakultas. Sehingga hubungan koordinasi akan lebih mudah karena terdapat bagian dari fakultas yang langsung mengawasi kegiatan dari komunitas tersebut. Selain itu, pembina juga melakukan pendampingan terkait kegiatan kajian ataupun diskusi yang harus dilakukan oleh KSPM. Selain itu, pembina melalui fakultas yang menghubungkan KSPM dengan lembaga pemerintahan.

\section{Komunitas dengan Pemerintah}

Komunitas dengan pemerintah memiliki hubungan collaborating. Dalam hubungan ini komunitas merupakan pelaku yang menaungi penyampaian literasi kepada masyarakat bersama perusahaan sekuritas. Pemerintah dalam hal ini BEI dan OJK memiliki peran yang sama dan juga berbeda. Dalam hubungan ini harus ada kepercayaan yang tinggi baik dari komunitas ke pemerintah maupun sebaliknya. Oleh karena itu, hubungan yang terjalin berbentuk collaborating. Sampai saat ini, peran pemerintah dalam berkolaborasi dengan komunitas terlihat dari pelaksanaan seminar kepada mahasiswa dan pelajar yang sudah melibatkan komunitas sebagai pelaksananya. Seperti yang diungkapkan ketua KSPM UIN Sunan Kalijaga di mana anggotanya dipercaya untuk menjadi panitia dari pelaksanaan seminar literasi pasar, selain itu KSPM juga mendapat kepercayaan dari BEI untuk melakukan kunjungan ke BEI dan belajar secara langsung di industri pasar modal.

6. Komunitas dengan Bisnis

Komunitas dan bisnis dalam hal ini memiliki hubungan collaborating yang memiliki ciri-ciri adanya pembagian sumber daya, risiko, tanggung 
jawab dan rewards (Roberts, 2004). Titik poin pengembangan program Yuk Nabung Saham terjadi di kolaborasi perusahaan sekuritas dan KSPM. Dalam pengembangan sebelumnya KSPM hanya membantu pengembangan program Yuk Nabung Saham melalui seminar yang diadakan BEI, dan perusahaan sekuritas hanya datang ketika acara tersebut. Selanjutnya investor atau calon investor ketika akan mengikuti program ini terlebih dahulu harus datang ke perusahaan sekuritas untuk membuka rekening efek. Tentu hal ini kurang efektif serta kurang menjangkau semua kalangan, oleh karena itu melalui kolaborasi perusahaan sekuritas dan KSPM diharapkan dapat meluaskan akses program Yuk Nabung Saham. Kolaborasi ini dengan adanya kunjungan ke daerah yang memiliki potensi investasi, dengan kata lain skemanya jemput bola. Kolaborasi yang dilaksanakan berupa KSPM melakukan penyampaian terkait pentingnya investasi dan posisi pasar modal di Indonesia. Kemudian perusahaan sekuritas melanjutkan dengan menyampaikan program Yuk Nabung Saham yang merupakan program kampanye pasar modal untuk meningkatkan investor di Indonesia. Selanjutnya, perusahaan sekuritas membuka peluang untuk pembukaan rekening efek sebagai syarat awal melakukan investasi di program Yuk Nabung Saham. Selain membuka rekening, masyarakat juga bisa langsung menabung saham dengan nominal Rp 100.000. Mengingat Yuk Nabung Saham merupakan program investasi dengan skema nabung saham yang dilaksanakan setiap bulan, maka perusahaan sekuritas dan KSPM akan rutin mengunjungi daerah tersebut setiap satu bulan sekali. Setiap daerah juga diperkenankan menunjuk satu koordinator untuk memudahkan pelaksanaan transaksi. Dengan adanya skema seperti ini diharapkan masyarakat akan lebih tertarik karena akses jangkauannya mudah. Penawaran skema ini juga sesuai dengan salah satu program OJK yakni Laku Pandai (Layanan Keuangan Tanpa Kantor dalam Rangka Keuangan Inklusif).

\section{Media dengan Bisnis}

Jenis hubungan media dengan bisnis berdasarkan skema penawaran di atas yakni collaborating, di mana media berperan langsung untuk berinteraksi aktif dalam pelaksanaan program peningkatan program Yuk Nabung Saham. Media berhubungan secara intensif terhadap bisnis sebagai upaya untuk mempublikasikan kegiatan yang dilaksanakan sehingga mampu menarik masyarakat lain untuk ikut serta dalam pelaksanaan selanjutnya. Selain itu, media juga berperan untuk memasarkan produk yang dalam hal ini program Yuk Nabung Saham kepada masyarakat secara luas. Sehingga media dengan bisnis memiliki tanggung jawab yang saling terkait serta terdapat pembagian risiko satu sama lain. Oleh karena itu jenis hubungan yang diterapkan yakni collaborating. 
8. Media dengan Akademisi

Media dengan akademisi memiliki hubungan networking, di mana menurut Roberts (2004) hubungan ini menjadi satu-satunya hubungan informal dan memiliki kekuatan paling rendah di antara hubungan lainnya. Media yang berperan sebagai pemberi informasi dan publikasi produk tidak harus berhubungan secara langsung dan intensif dengan akademisi, sehingga hubungan ini tidak bersifat formal. Selain itu, media masuk kepada seluruh elemen stakeholder namun tidak memiliki peran secara langsung kecuali dengan bisnis dan pemerintah. Dalam hubungan networking dari media kepada akademisi, media hanya berperan memberikan informasi dari pihak pemerintah serta pihak bisnis dan komunitas kepada akademisi. Sehingga tidak perlu adanya hubungan secara berkelanjutan dengan ditambah komitmen waktu.

\section{Media dengan Komunitas}

Jenis hubungan media dengan komunitas yakni networking. Menurut Robert (2004) networking merupakan hubungan informal yang tidak memerlukan waktu secara intensif dalam berhubungan. Media yang berperan sebagai publikasi terhadap semua kegiatan yang dilaksanakan komunitas dan bisnis dalam pengembangan produk Yuk Nabung Saham sudah mencakup perannya dalam model penta helix. Komunitas yang berkolaborasi dengan bisnis menjadikan tidak perlunya ada hubungan intensif kembali dengan media, mengingat hubungan media dengan bisnis sudah berupa collaborating.

\section{Bisnis dengan Akademisi}

Bisnis dengan akademisi memiliki jenis hubungan networking. Dalam hal ini bisnis dengan akademisi tidak membutuhkan pembagian sumber daya maupun pembagian risiko. Hubungan bisnis dan akademisi tidak terjalin secara formal. Bisnis berkolaborasi langsung dengan komunitas, di mana komunitas berada pada koordinasi akademisi. Selain itu, akademisi berkolaborasi langsung dengan pemerintah yang memiliki hubungan collaborating dengan bisnis. Sehingga hubungan antara bisnis dan akademisi cukup di networking.

\section{Implementasi Program Laku Pandai Sebagai Upaya Peningkatan Sadar Investasi Masyarakat}

Penelitian ini membahas tiga poin penting yang saling berkaitan

yakni investasi merupakan salah satu elemen pengeluaran negara yang berpengaruh secara signifikan terhadap pertumbuhan ekonomi. Namun, di Indonesia perkembangan investasi dan masyarakat yang terjun dalam 174| IQTISHODUNA Vol. 15 No. 2 Tahun 2019 http://ejournal.uin-malang.ac.id/index.php/ekonomi 
investasi sangat minim, data Hasil Survei Inklusi Keuangan menyebutkan hanya 1,3\% dari 250 juta penduduk yang melakukan investasi di pasar modal. Hal ini menjadi perhatian yang serius dari pemerintah, berbagai upaya terus dilakukan untuk mengembangkan investasi di Indonesia dan menjadikan masyarakat yang sadar investasi. Oleh sebab itu, penelitian kali melalui pengembangan program BEI yakni Yuk Nabung Saham dimaksimalkan dalam pemasaran menggunakan metode penta helix. Di mana bersinerginya stakeholder-stakeholder untuk mengembangkan program Yuk Nabung Saham secara terhubung. Mengingat, selama ini pengembangan program masih hanya dikembangkan oleh stakeholder yang menciptakan dan pada lingkungan tertentu. Sehingga akan dalam mencapai lingkup yang luas.

Penawaran utama dalam penelitian ini yaitu penerapan laku pandai dalam meningkatkan masyarakat yang sadar investasi. Laku Pandai (Layanan Keuangan Tanpa Kantor dalam Rangka Keuangan Inklusif) merupakan program yang diterapkan OJK sebagai program perbankan untuk membuka layanan keuangan melalui kerja sama dengan pihak lain (agen bank), dan didukung dengan penggunaan sarana teknologi (Otoritas Jasa Keuangan, 2015.). Melalui program ini perbankan diharapkan bisa meluaskan akses pelayanan terutama bagi masyarakat yang unbankable sehingga dapat meningkatkan keuangan inklusif di Indonesia. Oleh karena itu, peneliti mencoba memasukkan program laku pandai dalam pengembangan investasi di Indonesia dengan mengkolaborasikan (collaborating) antara komunitas, bisnis dan pemerintah yang berperan langsung dalam transaksi investasi Yuk Nabung Saham. Realita yang terjadi sekarang, stakeholder tersebut berperan dalam pengembangan program ini secara tidak maksimal. Poin tidak maksimal disini karena, pemerintah dan komunitas berkolaborasi pada edukasi dan inklusi pasar modal hanya dengan mahasiswa dan pelajar yang sebenarnya mahasiswa dan pelajar dapat diedukasi hanya oleh komunitas dengan pendampingan pemerintah. Mengingat komunitas sudah mendapatkan edukasi yang matang dari pemerintah. Seperti yang disampaikan oleh ketua Organisasi Pasar Modal Universitas Negeri Semarang, Hendru menyatakan bahwa fakultas sudah melakukan kerja sama dengan BEI, sehingga organisasi mendapat beberapa fasilitas dari BEI, seperti edukasi, aplikasi trading bahkan peralatan lab.

Selain itu, dalam pelaksanaan program Yuk Nabung Saham, calon investor diminta datang langsung ke perusahaan sekuritas untuk dapat melakukan pembukaan rekening sebagai prosedur penggunaan program ini. Tentu hal ini sangat memberatkan, mengingat perusahaan sekuritas hanya terletak di titik kota provinsi (yuk nabung saham. idx. co. id). Oleh sebab itu, perusahaan sekuritas harus terlibat dalam kolaborasi pemerintah dan komunitas dalam edukasi dan inklusi pasar modal. Berikut skema laku pandai 


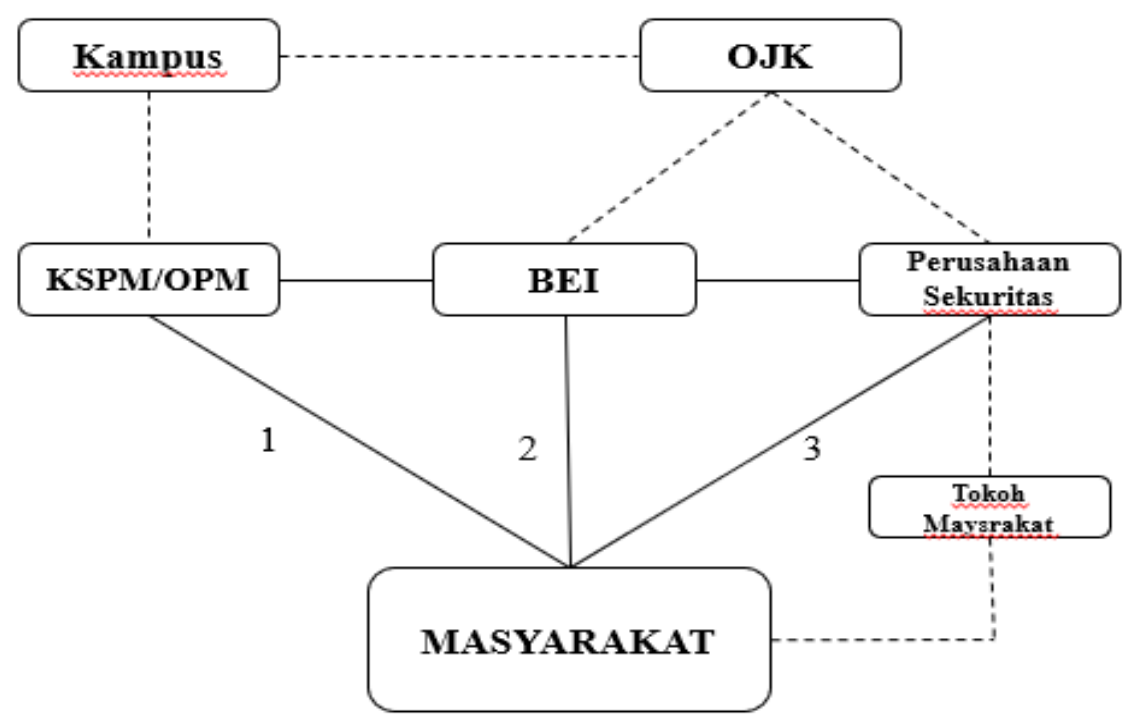

\section{Gambar 4. Skema Laku Pandai Peningkatan Masyarakat yang Sadar Investasi}

Sumber: Diolah oleh penulis

Terdapat garis koordinasi antara kampus dan $0 \mathrm{JK}$, mengingat untuk pelaksanaan pengembangan program Yuk Nabung Saham OJK harus sudah memiliki hubungan kerja sama dengan kampus. Selanjutnya kampus yang merupakan penanggung jawab dan pembina dari KSPM atau Organisasi Pasar Modal (OPM) juga memiliki garis koordinasi, sehingga KSPM tidak lepas dari controling dan jangkauan kampus. Tidak hanya kampus, OJK juga memiliki garis koordinasi dengan BEI dan perusahaan sekuritas. Walaupun BEI pencetus program Yuk Nabung Saham, namun pengawasan dan pemberi kebijakan di OJK sehingga OJK layak untuk melakukan koordinasi kepada keduanya. Kemudian terdapat garis lurus antara KSPM, BEI dan perusahaan sekuritas yang berarti terdapat kolaborasi di antara ketiganya dalam mencapai tujuan ke masyarakat. Secara teknis pelaksanaan, ketiga stakeholder akan melakukan jemput bola ke masyarakat dengan peran yang berbeda. Media juga berperan dalam skema ini, namun tidak bergaris resmi karena hubungannya nanti hanya networking.

1. KSPM/OPM

Dalam program ini, KSPM memiliki peran untuk mengedukasikan kepada masyarakat terkait teori, konsep dan pentingnya investasi bagi masyarakat untuk masa depan. KSPM berperan untuk memperbaiki pola pikir masyarakat terkait cara menyikapi uang dengan bijak sebagai wujud persiapan masa depan. Mengingat, secara naluri anak mahasiswa lebih dekat dengan masyarakat. Selain itu, KSPM yang 176| IQTISHODUNA Vol. 15 No. 2 Tahun 2019 
nantinya akan mendampingi masyarakat untuk bertransaksi di program Yuk Nabung Saham. Pendampingan dilakukan setiap bulan di mana KSPM nanti yang akan rutin untuk berkunjung ke setiap daerah. Langkah KSPM ini sebagai penguat dari program edukasi BEI melalui Sekolah Pasar Modal (SPM) di mana jangkauan edukasi KSPM lebih kecil, yaitu desa. Mengingat program SPM sedang dikembangkan di kota yang ada di Indonesia.

2. BEI

Sebagai lembaga pemerintahan, BEI berperan untuk mengampanyekan terkait program Yuk Nabung Saham dan memahamkan masyarakat bahwa investasi ini sesuai dengan syariah. selain itu, BEI juga menanamkan perasaan nasionalisme kepada masyarakat terkait kegiatan investasi memiliki pengaruh terhadap pertumbuhan ekonomi. Dalam usaha jemput bola ini, BEI tidak ikut mendampingi setiap bulannya.

\section{Perusahaan Sekuritas}

Stakeholder ini memiliki peran sebagai perantara untuk transaksi perdagangan efek. Mengingat titik kantornya berada di kota yang belum mampu diakses semua kalangan, dalam program ini perusahaan sekuritas berperan untuk melayani pembukaan rekening efek dan rekening dana investor. Sehingga masyarakat daerah tidak perlu datang ke kantor hanya perlu mengikuti kegiatan ini dan membawa persyaratan untuk pembukaan rekening. Beberapa perusahaan sekuritas sudah memiliki layanan Yuk Nabung Saham secara online, disini perusahaan sekuritas dapat mengedukasikan kepada masyarakat terkait transaksi secara online-nya. Selanjutnya, perusahaan sekuritas juga dapat menunjuk tokoh masyarakat sebagai wakil dari masyarakat untuk setoran setiap bulan. Mengingat setiap bulan tidak semua perusahaan sekuritas dapat ikut mendampingi untuk setorannya.

Kolaborasi ketiga stakeholder tersebut dan penerapan model penta helix ini sesuai dengan daerahnya masing-masing. Daerah yang menjadi titik awal sasaran yakni daerah dengan potensi investasi yang tinggi (daerah dengan pendapatan per kapita tidak dibawah rata-rata). Sebagai contoh di Semarang, data dari web yuknabungsaham.co.id menyebutkan terdapat 12 perusahaan sekuritas yang ada di kota tersebut. Bersama dengan 12 perusahaan sekuritas tersebut, KSPM dari kampus di Semarang berkolaborasi misalnya UNNES, UIN Walisongo, UNDIP dan lainnya baik nantinya KSPM yang turun akan dirandom 
Muhammad Al Faridho Awwal, Dewi Wahyu Setyo Rini

atau sesuai universitas hal itu bisa menjadi kebijakan OJK dan kampus. Hal ini dikoordinasi oleh kampus dan OJK Semarang secara langsung. Sehingga, garis pelaksanaannya akan lebih mudah. Jadi, pengembangan program Yuk Nabung Saham dapat tersebar secara merata dan dalam kurun waktu yang tidak terlampau jauh antar daerahnya.

\section{Kesimpulan}

Investasi merupakan salah satu elemen pengeluaran negara yang memiliki pengaruh signifikan terhadap pertumbuhan ekonomi. Pengeluaran yang dimaksud yakni konsumsi individu, pengusaha atau pemerintah yang tidak dikonsumsi namun dikelola atau diproduksi oleh pihak debitur yang kemudian hasil pengelolaan tersebut akan mendatangkan keuntungan baik bagi investor maupun debitur. Selain keuntungan atau pendapatan, pengelolaan dana investasi dapat mengurangi angka pengangguran mengingat pengelolaan suatu proyek pasti membutuhkan sumber daya manusia untuk mengelolanya. Namun, keadaan investasi di Indonesia masih sangat mengenaskan. Hanya $0.2 \%$ atau 600 ribu penduduk Indonesia yang ikut investasi. Padahal Indonesia memiliki penduduk dengan angka ratusan juta yang bisa dibilang tidak sedikit. Hal ini tentu menjadi tantangan tersendiri bagi pemerintah. Oleh sebab itu, di tahun 2015 BEI sebagai tempat yang mewadahi operasional perdagangan efek atau tempat yang melayani transaksi investasi meluncurkan sebuah kampanye untuk meningkatkan minat investasi di pasar modal.

Program Yuk Nabung Saham, dikemas dengan apik agar mampu mengakses semua kalangan. Dengan skema nabung saham, program ini dalam jangka waktu satu tahun sudah meningkatkan inklusi pasar modal dari $0.1 \%$ menjadi $1.3 \%$. Tentu ini pencapaian yang luar biasa, oleh sebab itu program ini harus terus ditingkatkan. Penelitian ini menawarkan model penta helix sebagai model sinergi stakeholder dalam pengembangan program ini, yakni melibatkan pemerintah, akademisi, bisnis, komunitas dan media. Hubungan yang terjalin didalamnya berbeda-beda, namun titik utama rekomendasi penelitian ini yaitu hubungan kolaborasi antara perusahaan sekuritas (bisnis), KSPM (komunitas) dan pemerintah dalam implementasi jemput bola dengan memanfaatkan skema laku pandai yang diterapkan OJK untuk program perbankan. Sehingga diharapkan dapat meningkatkan literasi kepada masyarakat dan meningkatkan investor di Indonesia

Selain penawaran skema, peneliti juga melakukan uji pengaruh menggunakan analisis Error Correction Model (ECM) untuk mengetahui tingkat pengaruh investasi terhadap pertumbuhan ekonomi. Hasil pengolahan data menyebutkan dampak tingkat investasi PMDN terhadap pertumbuhan ekonomi sangat signifikan baik dalam jangka panjang maupun jangka pendek. 


\section{Daftar Pustaka}

Ajija, S. R. 2011. Cara Cerdas Menguasai E Views. Jakarta: Salemba Empat.

Bursa Efek Indonesia (BEI). 2018. Kampanye Yuk Tabung Saham. Diakses pada 25 Mei 2018. Yuk nabung saham. idx. co. id.

Direktorat Pasar Modal Syariah Otoritas Jasa Keuangan. 2015. Roadmap Pasar Modal Syariah 2015-2019. Otoritas Jasa Keuangan. Diakses pada 28 Mei 2019.

https://www.ojk.go.id/id/kanal/syariah/beritakegiatan/publikasi/Doc ument/roadmap-pms_2015-2019

Hadi, S. 1990. Metodologi Research Jilid I. Yogyakarta: Andi Offset

Himawan, A \& Tanjung A. 2017. Jokowi Sadar Investasi Jadi Kunci Pertumbuhan Ekonomi. Suara.com. Diakses ada 26 Juni 2018. https://www.suara.com/bisnis/2017/08/29/165824/jokowi-sadarinvestasi-jadi-kunci-pertumbuhan-ekonomi.

Insukrindo. 1999. Pemilihan Model Ekonomi Empirik dengan Pendekatan Koreksi Kesalahan. Jurnal Ekonomi. Vol. 14 (1). Diakses pada 1 Juni 2019. Keynes and Jhingan, M. L. 2003. Ekonomi Pembangunan Dan Perencanaan. Jakarta: PT. Raja Grafindo Persada.

Kusumaningtuti, S. Seminar Investasi Pasar Modal Indonesia di PT Pembangunan Jaya Ancol Tbk (PJAA) pada 26 Mei 2016.

Destrianita, K. 2015. BEI: Yuk, Nabung Saham!. Tempo.com. Diakses pada 26 Mei 2019. https://bisnis.tempo.co/read/728116/bei-yuk-nabungsaham/full

Muhammad. 2014. Kointegrasi dan Estimasi ECM pada Dat Time Series. Jurnal Konvergensi. Vol. 4 (1). Diakses pada 26 Mei 2019.

Muhyi, H. A., Chan, A., Sukoco, I., \& Herawaty, T. 2017. The Penta helix Collaboration Model in Developing Centers of Flagship Industry in Bandung City. Review of Integrative Business and Economics Research. Vol. 6 (1). Pp.412-417.

Nugroho, A. Seminar Investasi Pasar Modal Indonesia di PT Pembangunan Jaya Ancol Tbk (PJAA) pada 26 Mei 2016.

Nurmalia, A, Zenuri, M. 2018. Strategi Pengembangan Usaha Mikro, Kecil, dan Menengah (UMKM) dengan Model Penta helix (Studi pada UMKM Sentra Bordir dan Konfeksi Desa Padurenan Kecamatan Gebog Kabupaten Kudus. Naskah Publikasi. Universitas Muhammadiyah Yogyakarta. $\begin{array}{lllll}\text { Diakses } & \text { pada } & 26 & \text { Mei } & 2019 .\end{array}$ http://repository.umy.ac.id/handle/123456789/188431

Otoritas Jasa Keuangan. 2017. Otoritas Jasa Keuangan. 2017. Strategi Nasional Literasi Keuangan Indonesia (Revisit 2017). Diakses pada 28 Mei 2019. https://www.ojk.go.id/id/berita-dan-kegiatan/publikasi. 
Muhammad Al Faridho Awwal, Dewi Wahyu Setyo Rini

Riyadi, A. 2016. Analisis Faktor-Faktor Yang Mempengaruhi Minat Mahasiswa untuk Berinvestasi di Pasar Modal. Skripsi Fakultas FEBI UIN Sunan Kalijaga, Yogyakarta. Diakses pada 25 Mei 2019. http://digilib.uinsuka.ac.id/22427/1/12391024_BAB-I_IV-atau-V_DAFTAR-PUSTAKA.pdf.

Robert, J. M. 2004. Alliances, Coallitions and partnership: Building Collaborative Organizations. New York: New Society Publisher.

Slamet, R ., Nainggolan, R., Ramdani H., Hendriyanto, A. 2017. Strategi Pembangunan UKM Digital dalam Mengahadapi Era Pasar Bebas. Jurnal Manajemen Indonesia. Vol. 16(2). Diakses pada 25 Mei 2019.

Sturesson, E. Lindmark, Roos. 2009. Collaboration for Innovation - A Study in the Öresund Region. LUP Student Paper Lund University Libraries Sweden. Diakses pada 29 Mei 2019.

Sumastuti. 2006. Keunggulan NPV Sebagai Alat Analisis Uji Kelayakan Investasi Dan Penerapannya. Jurnal Manajemen (7). Pp. 121-140. Diakses pada 20 April 2019

UU No 19 Tahun 2008 Tentang Surat Berharga Syariah Negara (SBSN)

UU No 8 Tahun 1995 Tentang Pasar Modal

Widarjono, A. 2013. Ekonometrika: Pengantar dan Aplikasinya. Edisi Keempat. Yogyakarta: UPP STIM YKPN. 